\title{
MAPPING GEOLOGY AND STRUCTURAL FEATURES OF KAZAURE SE, NW NIGERIA: JUSTIFYING GROUNDWATER POTENTIAL MODEL
}

\author{
Kankara Ibrahim Aliyu ${ }^{A}$ and Idris Musa Ado ${ }^{B}$ \\ Received: May 11, 2020 | Accepted: June 25, 2020 \\ DOI: 10.5937/ZbDght2001001K
}

\begin{abstract}
This research is focused on the evaluation of lithological units of the Kazaure area, north western Nigeria. The geological mapping was carried out using topographical sheet on a scale of 1:50,000. The methodology adopted for the study involved Field studies and petrographic analysis, which included close observation of outcrops and their exposures, their mineralogy and structures as well as recording of their geographical locations and strike/dips of foliations. The analysis revealed that, the area is underlain by three (3) major rock units: muscovite schist, porphyritic granite and sandstone (Chad Formation) with quartzite occurring as a minor lithology. The trend of lineaments shows a predominating NE-SW direction in the rocks. The cations and anions analyzed revealed that they are within the range of acceptable standard, except the higher concentration ofand which might have formed from acidic water of the area. The dominant water facies in the study area is -. These facies might have taken their sources from rock-water interaction of silicate minerals (Plagioclase feldspar). Wilcox plot of salinity hazard of the water samples indicated that, the water of the area is good for irrigation. It can be classified, the value of electrical conductivity of 0 - 250 excellent, 250 - 750 good, $750-2250$ doubtful and $>2250 \mu \mathrm{S} / \mathrm{cm}$ unsuitable. It is strongly recommended that the stake holders and governments at all levels enforce further studies of adjacent sheets for sustainable groundwater exploration and exploitation for better human and other domestic use.
\end{abstract}

Keywords: Geology, Lithology, Facies, Kazaure SE, NW Nigeria

A Department of Geology, Federal University Dutsin-Ma, Katsina State, Nigeria; corresponding author: aibrahim@fudutsinma.edu.ng

B Department of Geology, College of Advanced and Remedial Studies, Tudun-Wada, Kano, Nigeria. 


\section{INTRODUCTION}

The task before Geographic Information Sciences (GIS) is to effectively be used as a tool for mapping of groundwater quality, determining water availability, preventing flooding, understanding the natural environment, and managing water resources on a local or regional scale. GIS technologies have great potential for use in groundwater hydrology.

The geology of Kazaure northeast (Figure 1) has been classified into four (4) major lithological units namely: muscovite schist, quartzite, granite and sandstone (Black et al, 1979; Ajibade et al, 1987; Kankara, 2019). For this work, schist and quartzite were weighted as having a slightly higher normalized groundwater potential (15 and 11 respectively) in comparison to the granites with respective weights of 9. The Chad Formation was given normalized weights of 65 . The basement rock units are more productive at the base of the weathered zone where the rocks have been broken down to sand size and larger fragments that are not subjected to extensive weathering process.

Consequently, sandstone (Chad Formation) is a good aquifer for it has high groundwater potential, because it has higher porosity and permeability (McCurry, 1976). It is followed by muscovite schist, with higher porosity, low permeability while quartzite and porphyritic granite which are only good aquifer when they are fractured.

The geology of the area (see Figure 1) controls and influences the pattern of the drainage. The drainage pattern is mostly dendritic. Highly weathered minerals such as muscovite, biotite and feldspar of the metasediments of the area, result to the formation of secondary clay minerals (kaolinite). Alteration of these minerals favoured a relatively high storage capacity but low permeability of groundwater (Amudu et al, 2011). Low permeability produced fine drainage texture which indicates a high frequency of streams and its tributaries in a dendritic pattern (tree branches form), especially near matasediment ridges of Kazaure area (Figure 1). Major rivers in the area include, Tuwari, Gari, Kiye, Sabke and Tagwai.

The Tuwari River flow northeastwards through a rugged terrain and turn southeastern near Kazaure town. River Gari flows northeastwards across regional strike to its junction with the Tagwai River, from where it changes course to a more easterly flow direction similar to that of River Kiye (Figure: 1). However, River Kiye is an important river and empties into lake Kiye. Other lakes are Dandi, Dakwat, Kwaita and Wawan-Rafi.

Many of the new structures found on the rocks were cut by post-tectonic structures such as younger pegmatites. Locality known as Kazaure ridge is a good example, with occurrence of xenoliths. At this locality, with a strike joint of $141^{\circ}$ the joint directions control the direction of the rivers. The south and SW portion of the area are flat lying, with almost absence of prominent inserlbergs or boulder outcrops. At the southern part of this area, the landscape is generally peneplained rocks that are found in the area are discussed below) Usually, in the area there are some intrusions of few sandstones found on older granites, but this often exist rarely in the mapped area.

The contact between younger metasediments and basement complex are sharp and were covered in many locations. There is however, a gradual change between the schist 
and granite. There is also a sharp change between the schist because of the variation in the colors, textures and mineral compositions.

The occurrence of schist in the terrain provided additional evidence for crustal remobilization. Areas of basement that have been subjected to repeated cycles involving deposition of supracrustals, regional deformation, metamorphism and reactivation, followed by erosion and renewed deposition of supracrustals, are commonly referred to as being polycyclic (Arthur, 1982). Stages in the modification of supracrustals and granitic intrusions during later reactivation of the basement in the area, where syn-tectonic and late-tectonic granites has been emplaced. Complexly deformed relics are all that remains of the older supracrustal belts because they will tend to be in the antiformal regions between the new synformal supracrustal belts.

The geology of the area influences the aquifer properties for a lithological unit. Porosity and permeability of a rock determines its quality as an aquifer. Sedimentary rocks are known to have a primary porosity and permeability while weathered crystalline rocks have secondary porosity and permeability (Gupta, 2003). However, fracturing can greatly increase the ability of crystalline rocks to serve as aquifers (Mostafa and Bishta, 2005) and indicators of secondary porosity and permeability are commonly sought when prospecting for groundwater in such terrains (Gupta, 2003; McDonagh et al, 2000)

\section{Aim and Objectives of the study}

The aim of this work is to map the geology and structural features, with the view to justifying the groundwater potential model of the area. The specific objectives include:

a) To identify the lithological units and structures, from field mapping of the area, on a scale of 1:50,000;

b) To develop a Geographical Information System (GIS) model through integration of different thematic layers generated from remotely sensed data of the area in order to evaluate groundwater potential of the area;

c) To determine the groundwater quality of the study area.

\section{MATERIALS AND METHODS}

Location and Accessibility: The area is located in the northwestern part of Kano State, about $65 \mathrm{~km}$ away from the Kano metropolitan. It also covers part of Jigawa and Katsina States. The whole area is part of Kazaure schist belt, northwestern Nigeria. It lies between latitude $12^{\circ} 30^{\prime} 00^{\prime \prime} \mathrm{N}$ to $12^{\circ} 45^{\prime} 00^{\prime \prime} \mathrm{N}$, and longitude $8^{\circ} 15^{\prime} 00^{\prime \prime} \mathrm{E}$ to $8^{\circ} 30^{\prime}$ $00^{\prime \prime} \mathrm{E}$, covering an area of about $770.063 \mathrm{~km}^{2}$ (Figure 2). It is accessible through major roads, namely: Kano-Danbatta-Kazaure-Daura road, Kazaure-Roni-Ingawa and Kazaure- Shuwaki-Lamba road. There are also numerous networks of footpath throughout the area.

The area is typical of Sudan Savanna tropical climatic zone of Nigeria, which is characterized by two distinctive seasons (dry and wet seasons). The dry season begins from 


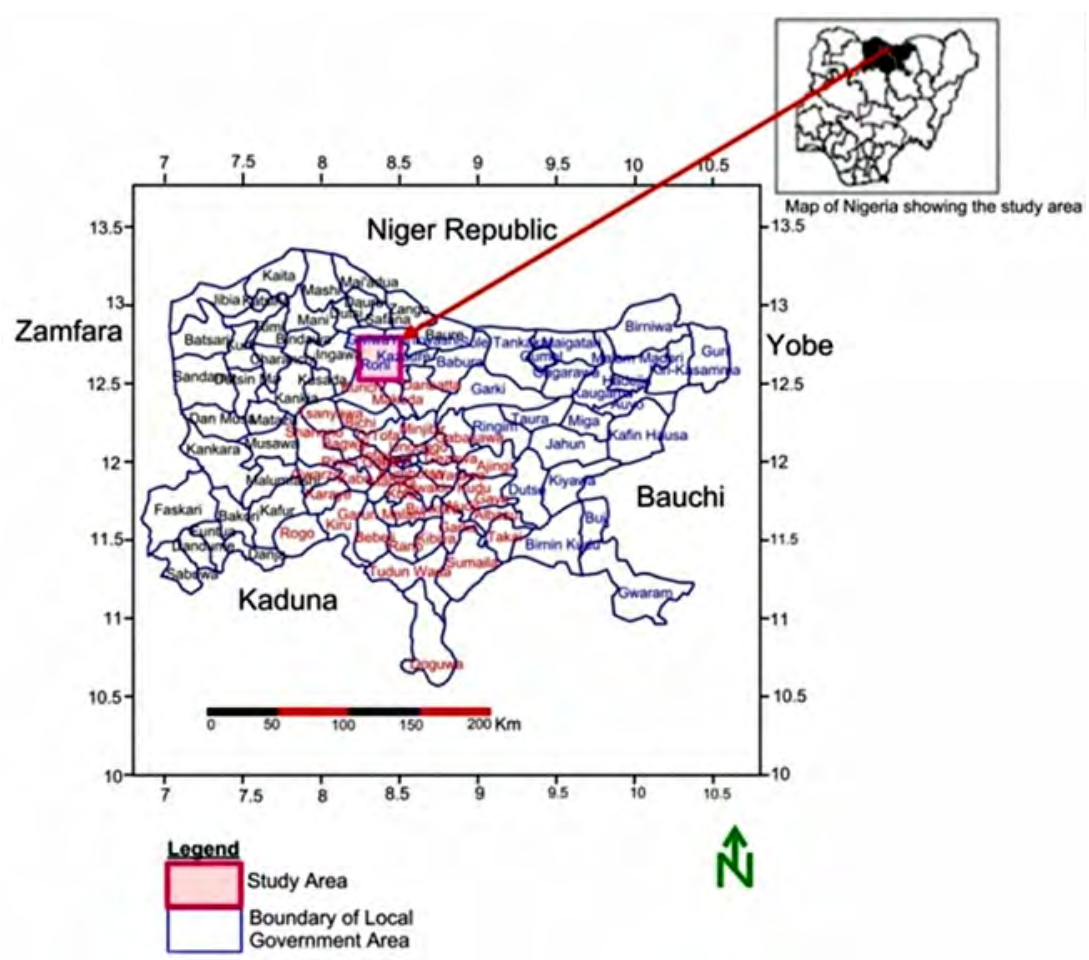

Figure 1. Location Map of Kazaure Area

October to April and is associated with low humidity, especially during the harmattan period. The wet or rain season commences from May to October, with mean annual rainfall of about $700-750 \mathrm{~mm} / \mathrm{a}$ (Figure 2). The annual range of temperature is between 27 to $34^{\circ} \mathrm{C}$ (Kankara, 2014).

The vegetation pattern is predominantly thorny shrubs with grasses of less than 2 $\mathrm{m}$ high. The few tall trees are thorn Acacia, Neem and Baobab which are scattered, and normally shed their leaves completely during the dry seasons. They have an average height of 10 to $15 \mathrm{~m}$. It is denser along river courses due to the presence of moisture which allows the vegetation to flourish.

Data Collection: The materials used in this study include; satellite imageries, GIS and RS softwares, review of the relevant existing literature such as text books, journals, topographic and geological maps, metric tape and combined meter Mi 806 (4 in 1), Global positioning system (GPS), compass clinometers etc. The methodology employed for this work is divided into three (3) phases. These are: (1) Remote Sensing interpretation of satellite imageries (2) field work (3) laboratory analysis

Geological Mapping: Geologic mapping was carried out on a scale of 1:50,000. It involved observing and recording (in the field notebook), occurrence of rock outcrops and exposures, noting geographical location, recording co-ordinate position obtained from Global Positioning System (GPS). Colour of rock, texture, mineralogy and structures were also examined. Strike and dip of foliation were measured with compass-clinom- 


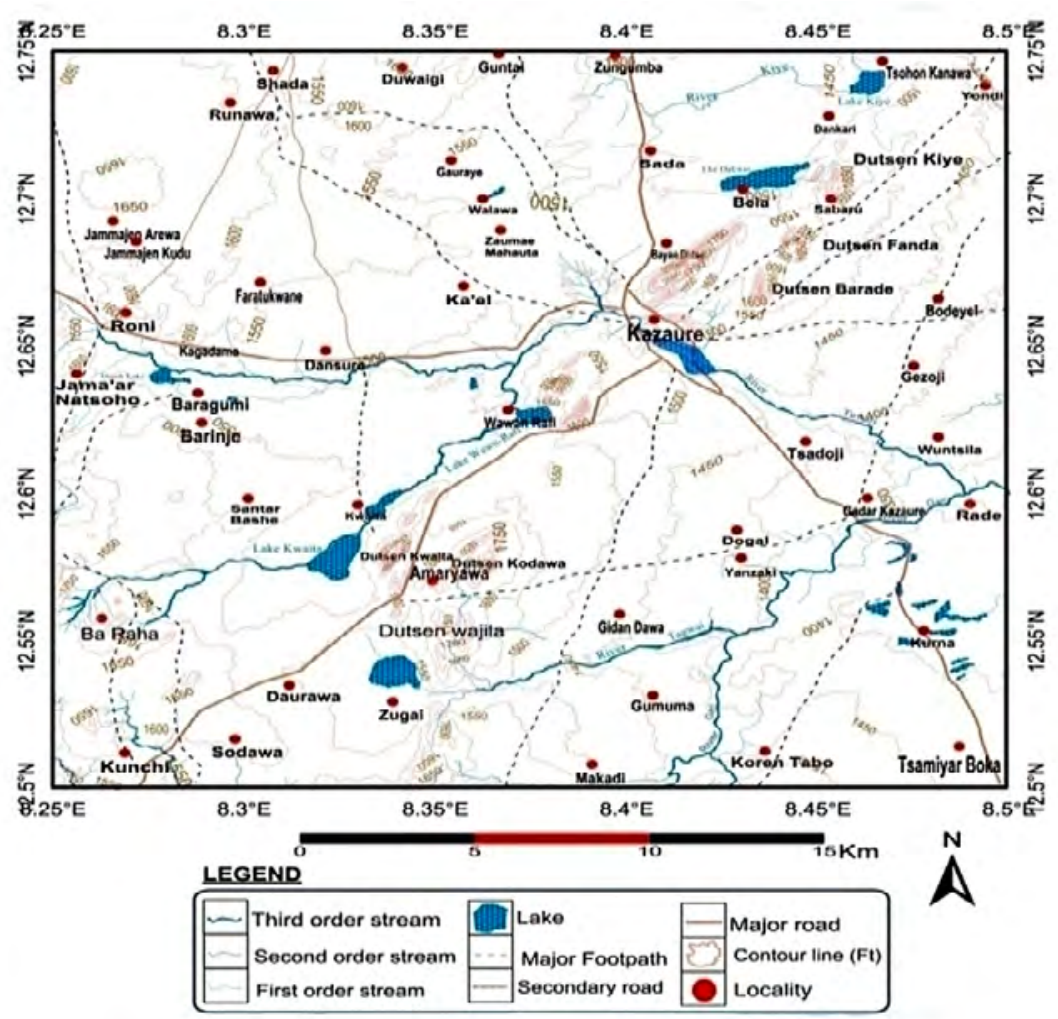

Figure 2. Drainage Map of Kazaure SE.

Source: Field work

eter and plotted on the base map. Traverses used include rivers and streams channels, foot paths and roads network. Rock samples were labeled using waterproof markers and stored in the sample bag for petrographic studies.

From the data obtained, a geological map was drawn with boundaries between lithologies inferred.The geological map was created from on screen digitization of the geology map of the area in the ArcGis environment. Classification was done on the basis of weights obtained from pair-wise comparisons done with the help of Expert Choice 10.0 software.

The drainage map was also obtained from on screen digitization of the drainage channels revealed in the topographical map in the ArcGis environment. The drainage density map was done from first order streams using the spatial analyst>kernel density menu in ArcGIS. Reclassification was done and weights assigned based on influence on groundwater potential.

Drainage proximity map was done from second and third order streams respectively after on screen digitization. Buffer zones around the streams were created and classified with the buffer zones distances around third order streams having more influence on groundwater potential than buffer zones around second order streams.

The Dem was classified into five classes and consecutive weights assigned to create the elevation map. On the other hand, the slope map was created using the $3 \mathrm{D}$ 
analyst $>$ Raster surface $>$ slope $>$ slope (percent rise) menu. The slope was then reclassified into five classes and weighs assigned on the basis of values obtained from pair-wise comparisons obtained using expert choice 11.0 software.

Integration of Thematic Maps: Six different thematic maps were integrated to generate the groundwater potential model (GWPM) for the study area using the raster calculator feature on ArcMap 9.3 software. It was produced by Weighted Linear Combination (WLC) where each class individual's weight was multiplied by the map scores and then adding the results.

\section{STRUCTURAL FEATURES OF THE KAZAURE AREA}

Fracture and Joints: Fractures occur in virtually all the outcrops mapped in the study area. The orientation of fractures varies across the different rock units in the area (Plate II, D and III, G). More than one joint set also occur in some outcrops. However, the dominant joint orientation is in the NW-SE direction (Figure 3, B).

Presence of joint may act as a channel for groundwater movement which results in increased secondary porosity and therefore, can serve as groundwater prospective zone (Mostafa and Bishta, 2005).

Foliations: Foliation is exclusively associated with matasediment rocks in the area. In the schist, schistosity is well developed and trend predominantly NE-SW. Phyllitic cleavage a continuous cleavage defined by the parallel orientation of platy minerals like muscovite was also observed in some location such as Amaryawa $\left(12^{\circ} 34^{\prime} 18.1^{\prime \prime} \mathrm{N}\right.$, $08^{\circ} 20^{\prime} 26.1^{\prime \prime E}$ ) (Figure I, C, C').

\section{Lineament Extracted from Satellite Images}

Lineaments are mostly concentrated within the crystalline rocks of Kazaure area. To a large extent, it controls the drainage pattern of the area, especially the River Tuwari by NW-SE fractures. The dominant lineament direction in the area is NE-SW (Figure 3, C) and conformed to the dominant trend obtained for strike of foliation plane of matasediments. Joints and fracture from the intruded rocks of the study area show a NW-SE trend (Figure 3, B).

\section{Discussion of Structural Features}

The general structural trend of the Kazaure Area are, N-S to NNE-SSW, NE-SW, of foliation planes and NW-SE of fractures and joints. The N-S to NNE-SSW of schistosity which was mostly measure at the west and southwest of the Kazaure town, are in agreement with (Danbatta, 1999; 2002) who have reported the the trend of foliation as N-S to NNE-SSW with westerly dip ranging from $45^{\circ}$ to the vertical. Futhermore, (Ibrahim, 2003) also observed N-S trending ridges west of the Kazaure town. In addition, the NESW and NW-SE of fractures are in agreement with (Danbatta, 1999; 2002). 

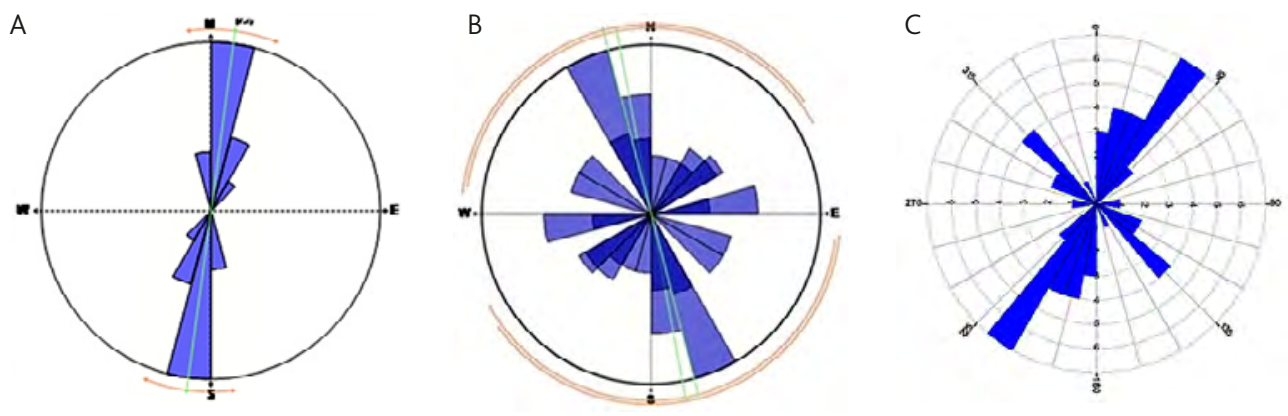

Figure 3. Rose Diagrams for Different Structures around Kazaure Area: A - Strike of foliation plane, B - Joints in Porphyritic Granites, and C - overall lineament extracted from the Advanced Spaceborne Thermal Emission and Reflection Radiometer (ASTER DEM) of the Kazaure area.

\section{Lineament}

The lineaments of Kazaure area were concentrated within the crystalline rocks (metasediments ridges) in the study area. As earlier stated, dominant trend of lineaments is NE-SW followed by NW-SE of fractures which dominantly control the drainage within the study area.. Lineament density in the area was classified into three categories namely: $0-1.79 \mathrm{~km} / \mathrm{km}^{2}, 1.79-6.25 \mathrm{~km} / \mathrm{km}^{2}$, and $6.25-14.76 \mathrm{~km} / \mathrm{km}^{2}$ Consequently, normalized weights of 9, 25 and 66 were assigned to the successive categories based on their perceived contribution to groundwater potential using pair-wise comparison.

Lineaments are manifestation of linear features that can be identified directly on the rock units or from remote sensing data while lineaments and their intersections play a

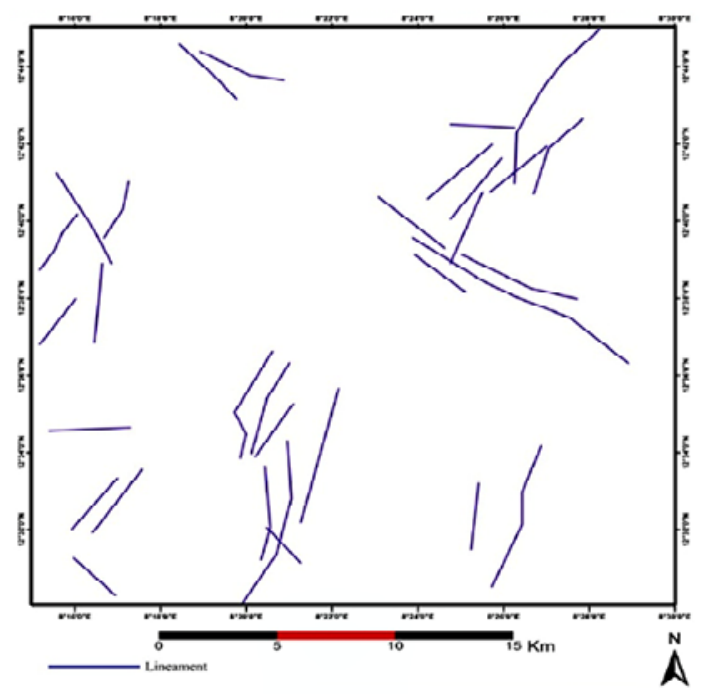

Figure 4. Lineament Map of the Kazaure Area 
significant role in the occurrence and movement of groundwater resources in crystalline rocks (Umaru et al, 2019). Since, in the study area more than $75 \%$ of the rocks occurring are crystalline rocks, the presence of lineaments may act as a conduit for groundwater movement which results in increased secondary porosity and, therefore, can serve as groundwater potential zone (Umaru et al, 2019).

\section{Thematic Layers (Maps) of the Kazaure Area}

Six (6) thematic maps were used to generate the groundwater potential map (GWPM). These include geology, drainage, lineament, slope, elevation, and water body proximity. .

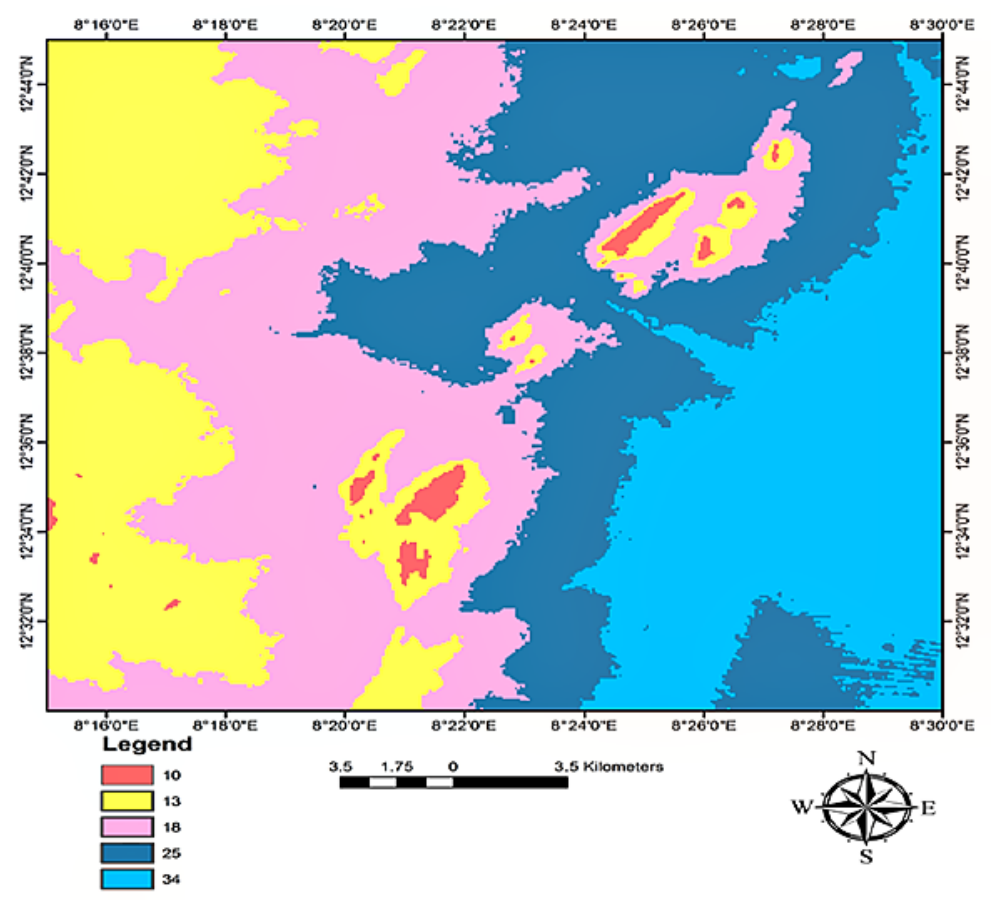

Figure 5. Classified Elevation Map of the Kazaure Area

\section{Drainage}

The area is characterised by a dendritic drainage pattern . The main streams (mostly third order streams) flow northeastwards and southeasterly respectively. In the drainage map of the area, a concentration of first order streams is seen on the areas underlain by crystalline rocks. The drainage density was reclassified into four classes namely: $0-50 \mathrm{~km} / \mathrm{km}^{2}$, $50-100 \mathrm{~km} / \mathrm{km}^{2}, 100-200 \mathrm{~km} / \mathrm{km}^{2}$ and $>200 \mathrm{~km} / \mathrm{km}^{2}$. Weights assigned to the subclasses in respect to their contribution to groundwater potential was 51,26, 14 and 9 correspondingly. This indicates that, areas with the lesser drainage, contribute more groundwater potential, because of the lesser the surface run off, and this favoured infiltration into the subsurface. 


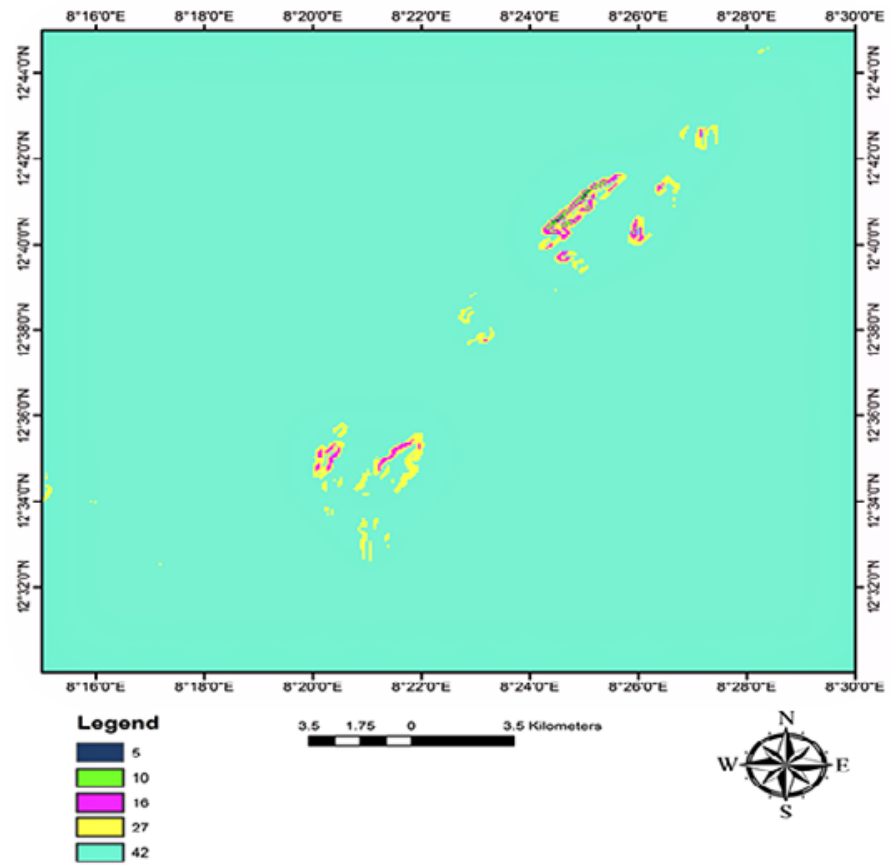

Figure 6. Classified Slope Map of the Kazaure Area

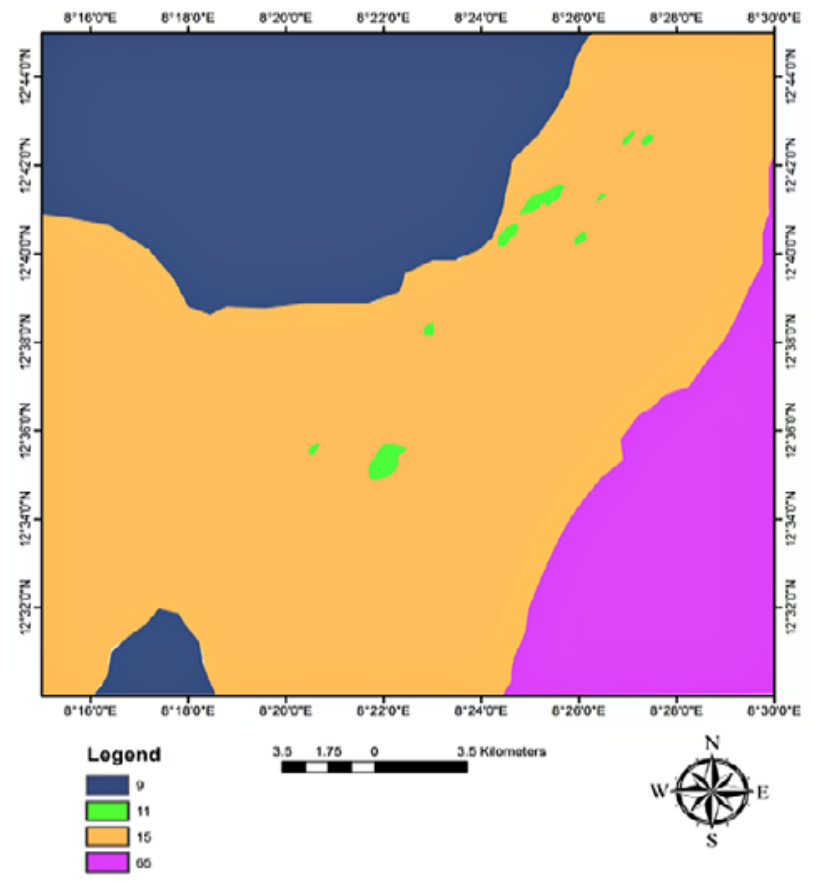

Figure 7. Classified Geological Map of the Kazaure Area 


\section{RESULTS AND INTERPRETATION}

Geology and Field Relationship: The study area is underlain by three major and one minor lithological unit. These are muscovite schist, porphyritic granite and sandstone (Chad Formation) with quartzite occurring as the minor lithology. The metasediments were intruded by Older Granitic rocks during the Pan Africa Orogeny; while the PlioPleistocene Chad Formation overlies these Precambrian rocks (Kankara, 2014; Figure 8)

Generally, the landforms conform to that obtainable in many parts of the Northern Nigeria. It is characterized by flat to undulating relief (Holt, 1982) The noticeable features are the discontinuous ridges of metasediments that trended NE-SW. The granitic rocks which are dome to whaleback occur in the northwestern part of the area. The peak point is on the Babban Dutse ridge near Kazaure town, and is about $106 \mathrm{~m}$ above the plain (Danbatta, 1999 and Ibrahim, 2003). The lowest relief is located around Gadar Kazaure southeastern part of the mapped area. Table 1 below shows the Aquifer prpperties of pump tested borehole samples collected.

Table 1. Aquifer Properties of pump tested boreholes within the Kazaure Area.

\begin{tabular}{|c|l|c|c|c|c|c|c|c|}
\hline $\mathrm{S} / \mathrm{N}$ & Location & $\begin{array}{c}\text { Northing } \\
\text { Decimal } \\
\text { Degree }\end{array}$ & $\begin{array}{c}\text { Easting } \\
\text { Decimal } \\
\text { Degree }\end{array}$ & $\mathrm{t}_{0}$ (day) & $\Delta \mathrm{s}(\mathrm{m})$ & $\mathrm{Q}()$ & $\mathrm{T}()$ & $\mathrm{S}(\mathrm{m})$ \\
\hline 1 & Belas & 12.69617 & 8.41928 & 0.000313 & 8.1 & 64.8 & 1.464036 & 4.575111 \\
\hline 2 & Gezoji 2 & 12.62622 & 8.47003 & 0.000417 & 0.44 & 123.6 & 51.40762 & 214.2155 \\
\hline 3 & Katoge & 12.64408 & 8.40919 & 0.000243 & 13.8 & 43.2 & 0.572884 & 1.392107 \\
\hline 4 & Tsabawa & 12.726 & 8.30436 & 0.00208 & 7.9 & 60.48 & 1.401027 & 29.18338 \\
\hline 5 & Roni Model & 12.65581 & 8.27056 & 0.000416 & 5.3 & 28.512 & 0.984495 & 4.095499 \\
\hline 6 & U/rogo & 12.66256 & 8.25872 & 0.000416 & 9.4 & 25.92 & 0.504625 & 2.09924 \\
\hline 7 & S/Bashe & 12.55797 & 8.30253 & 0.00083 & 11.2 & 51.84 & 0.847049 & 7.030508 \\
\hline
\end{tabular}

Source: Idris, 2012

\section{Location: Gezoji 2}

Data: $\mathrm{Q}=1.43 \mathrm{l} / \mathrm{s}=123.6 \mathrm{~m}^{3} /$ day, $\mathrm{t}_{0}=0.000417$ day, $\Delta \mathrm{s}=0.44 \mathrm{~m}, \mathrm{r} 0.015 \mathrm{~m}$

\section{Transmissivity}

$$
\begin{aligned}
& T=\frac{2.3 Q}{4 \pi \Delta s} \\
& T=\frac{2.3 \cdot 123.6}{4 \cdot 3.142857 \cdot 0.44} \\
& T=51.40762 \mathrm{~m}^{2} / \text { day }
\end{aligned}
$$


Where

- $Q=$ Constant pumping rate $1 / \mathrm{s}$

- $T=$ Transmissivity in $\mathrm{m}^{2} / \mathrm{s}$

- $s=$ Drawdown

- $\mathrm{t}=$ Time since pumping started.

- $r=$ radius of the well

\section{Storativity}

$$
\begin{aligned}
& S=\frac{2.25 \mathrm{Tt}_{0}}{r^{2}} \\
& S=\frac{2.25 \cdot 51.40762 \cdot 0.000417}{0.015^{2}}
\end{aligned}
$$

$\mathrm{S}=214.2155 \mathrm{~m}$

\section{Quartzite}

Popoolarly called younger metasediments, quartzite occurs as a patches normally at the top ofe metasediment ridges, trending NE-SW direction. It is coarse grained, reddish brown in colour, associated with ferroginzed iron. The younger metasediments consist of at least six distinct metasedimentary and metavocanic rocks. These are: quartzites, metapellites, metaconglomerates, metasandstones, metavolcanics and feruginous quartzites (Idris, 2012). The quartzites and metaphyllites are the most exposed rock types among the younger metasediments, with the metapelites the least exposed. Only a small proportion of the metasediment is formed by the metaconglomerates and metavolcanics.

Poorly exposed ferruginous quartzites which include feldspathic quartzites outcrops as boulders interbedded with N-S striking and elongated schist bodies, with the schists badly weathered and transformed to laterites in most places (Idris, 2012).

It occurs as large boulders in laterites, especially those observed in the SW of the study area. In some other places the feldspathic quartzites outcrops are found occurring as large bodies within highly weathered hills, as long as $5 \cdot 15 \mathrm{~m}$ (Danbatta, 1999). Much of the schist separating the metasediments are regarded as basement to the metasediments. This is further supported by the presence of already deformed boulders of granites in the conglomerate.

The presence of schist boulders in the conglomerate has proved the existence of older schist material predating the younger metasediments. The ferruginous quartzite outcrop as $1-3 \mathrm{~m}$ thick discontinuous sheets typically occurring in a N-S treading lateralized ridges. The lateralized ridges which consist of unbanded pisolithic ironstones are not studied in detail in this project, attention was only given to quartzite bands even in the study area. The exposed width of the ferruginous quartzite on the ridges is about $15-50 \mathrm{~m}$, and the strike length of the ridges is in the order of $1-3 \mathrm{~km}$. In some areas, the ferruginous quartzite is bounded by outcrops of hornblende granite, while towards the northeastthe lithology had been eroded away. 
The quartzite is fractured and broken up into boulders and pebbles at the top of the ridges, and, the eroded pieces littered the surounding plains. However, in places outside the area of study, the quartzite occured as a poorly outcropping dense rock in association with mica schists. The quartzite shows textural gradation from a massive to well foliated varieties and quartz-schist through the quartz schist also vein intermingled with bodies of phyllites. The quartz schist are also seen associated with the schist at exposed areas, as in areas to the southern part. The massive quartzite outcrop on top of the NNEtrending ridges, adjacent to some coverages of metapyllites intercalated with layers of these younger metasediments. However, the quartzite is in fault-contact with the vertical layers of beds of conglomerate rocks which dips towards eastern end of the mapped area. There is a sharp contract between these two lithologies in this place. The quartzitic rocks are cut by quartz veins in several exposures, some of which seem to be geometrically related to small folds

\section{Muscovite Schist}

Muscovite is potassium-dominated mica, and sometimes appears as an elongated mineral, bordering othorclase feldspars. In most of the migmatite rocks, muscovite exists as groundmass with very small size. Two types of muscovite here exist (i) the longelongated muscovite that deeps in WE direction and (ii) the other fine-grained ones that are groundmass in cloudy feldspars. The fine-grained muscovite has a high relief. They are generally light brown colored. They can be prismatic and exhibit parallel extinction, perfect cleavage and in one direction. Its chemical formulae is $\mathrm{KAl}_{3} \mathrm{Si}_{3} \mathrm{O}_{10}(\mathrm{OH}$, $\mathrm{F})_{2}$. Many of the crystals of muscovite show twinning and those which are near to the extinction position show the mottled appearance, which is characteristic of all micas (Kankara, 2014)

Occurences of schists which are older metasediments are most commonly observed as scattered and highly weathered relics of feldspatic schists outcrops along roads in the study area. Field relationships reveal this type of older schists as low- lying outcrops in the peneplain of the area. The schist occur as small lenses usually only exposed along river valleys where they have been deeply weathered. They constitute about $2 \%$ of the total rocks and are fine grained with foliation of the constituent minerals affected by intense weathering so that these features which often reveal the presence of several directions of schistosity are almost completely obliterated.

Gradational boundaries within the schist are ubiquitous and they grade into the adjacent gneisses for which they also exhibit conformable relationships. A number of geological observations in the schist rocks have important regional implications in the Funtua north east area. Therefore, for accurate interpretation and modeling of the overall regional geotectonic evolution of the schists, the outcome of the present research shall be compared to earlier works deduced on the other NW Nigeria Schist Belts. This can allow the formulation of a geotectonic model that will show how the geologic and structural framework of the schist and its adjacent areas has evolved. An attempt has also been made in this chapter to contribute to the evolutionary framework of the schist rocks. Deformational and metamorphic activities were associated to rock lithologies of the neighboring sheets. The Schist-migmatite-gneiss basement complex seems to be the 
oldest rock unit and considered to be derived from a pre-existing sedimentary series of schist (paragenesis), possibly Archaean, through several tectono-metamorphic episodes.

The rock unit occupied the northeast, central and southern part of the study area. It is fine to medium grained and reddish to brownish colour. Reddish colouration is imparted by the Banded Iron Formation (BIF), Bowden et al (1976), Turner, (1983) and Ibrahim, (2003) reported it, in the western part of the area (Figure 9, A).

In hand specimen the rock unit is highly foliated by the presence of mica group of minerals. In thin section minerals observed are muscovite, biotite, and feldspar. The strong foliation can be observed in thin section from preferred orientation of minerals such as muscovite and biotite (Figure 9 C, $\mathrm{C}^{\prime}$ and Figure 10 E, E'). Biotite shows a mild relief, pleichroism from greenish brown to green, and displays a parallel cleavage. Muscovite is colourless in thin section and exhibited high order interference colours and extinction (Figure 10, E). Quartz often occurred as polycrystalline crystals, displaying undulose extinction on rotating the stage as well as low grey interference colour. The boundaries between crystals are sutured (Figure 10, E). This is the characteristics of quartz from metamorphic source (Grant, 1978).

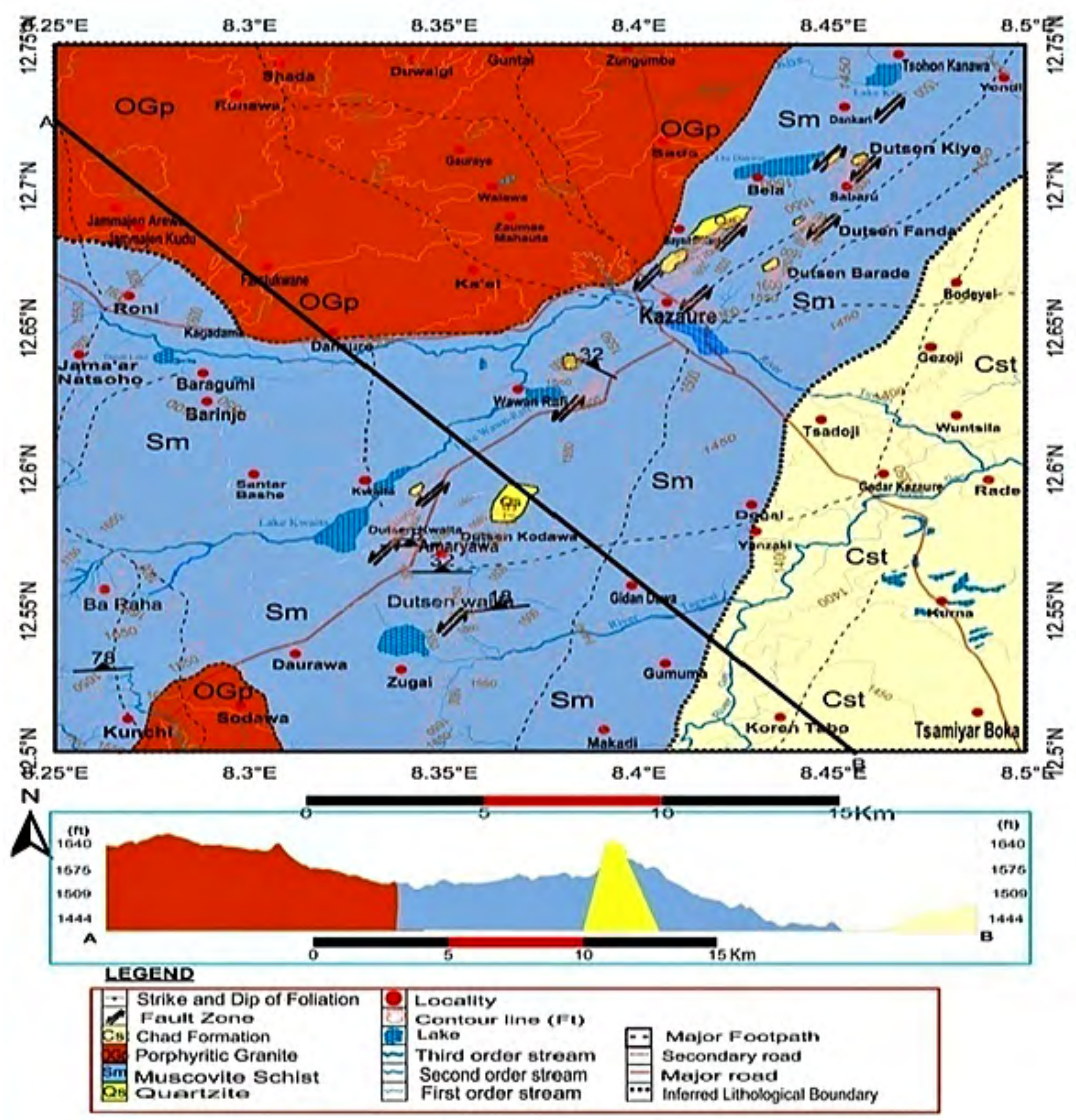

Figure 8. Geological Map of Kazaure area 

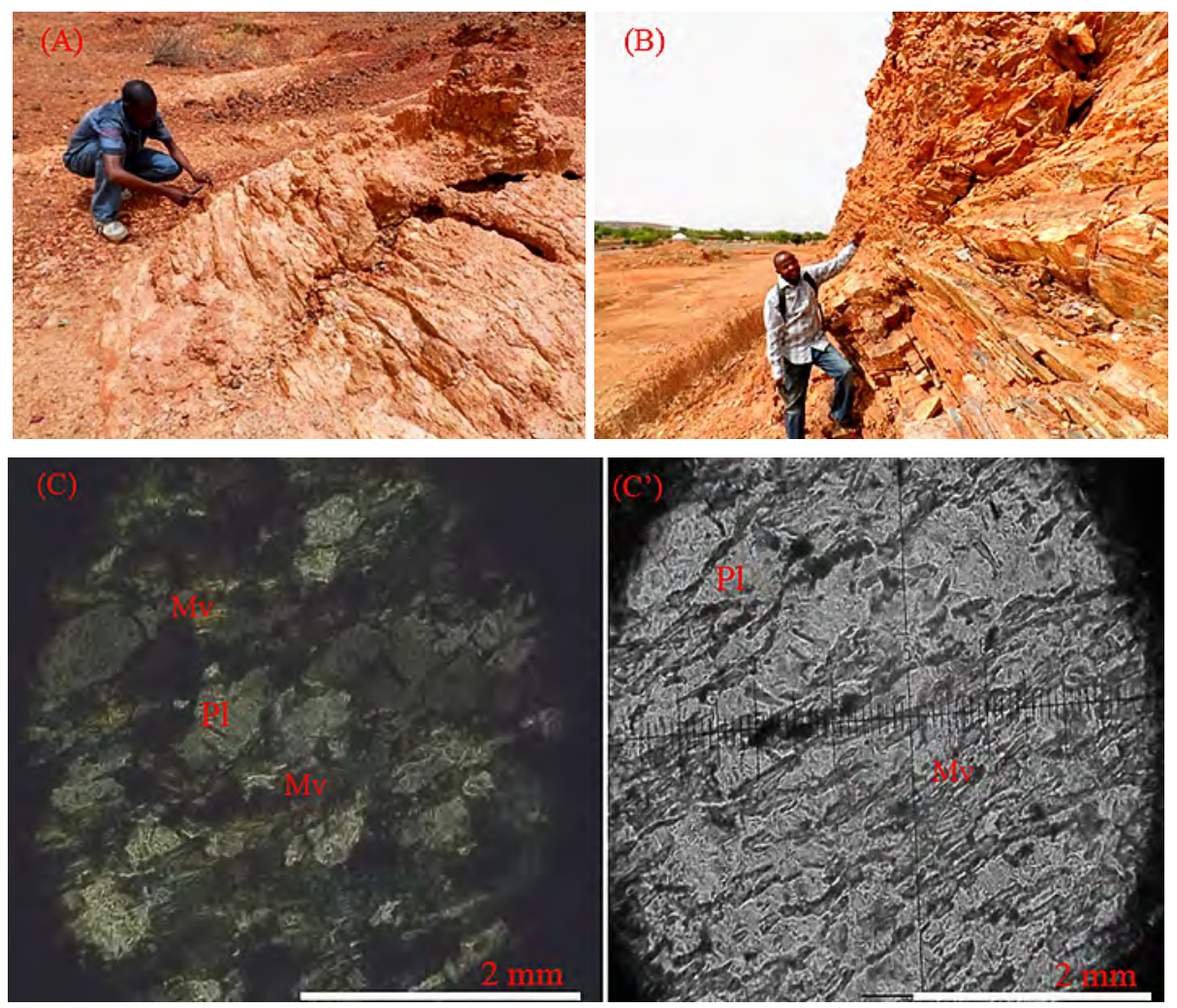

Figure 9. (A and B) Muscovite Schist ( $\left.12^{\circ} 31^{\prime} 45.9^{\prime \prime} \mathrm{N}, 08^{\circ} 15^{\prime} 44.7^{\prime \prime} \mathrm{E}\right)$ (B) $\left(12^{\circ} 34^{\prime} 18.1^{\prime \prime} \mathrm{N}\right.$, $08^{\circ} 20^{\prime} 26.1^{\prime \prime E}$ ) (C Photomicrographs of Muscovite schist XPL; (C') of Muscovite Schist PPL; NOTE: $\mathrm{Mv}=$ Muscovite and $\mathrm{Pl}=$ Plagioclase feldspar

\section{Porphyritic Granite}

This rock unit occurs mostly to the northwestern and as small pocket in the southern periphery of the study area. The rock is generally, coarse grained, whitish grey in colour and this coloration is imparted by the presence of plagioclase feldspar (Figure 11: F, $\mathrm{G}$ and $\mathrm{H})$. The rock is not foliated and also intruded the matasediment rocks of the area (Figure 8).

In hand specimen, the minerals that can be identified include feldspar, quartz, biotite and muscovite in order of their abundance. Texturally, grains of feldspars and/or quartz up to $3 \mathrm{~cm}$ in diameter were measured (Figure 11, H)

Thin section visual observation and deduction of the mineral modal composition shows that quartz has (74\%), microcline (11\%), plagioclase (5\%), orthoclase (7\%), muscovite $(2 \%)$ and biotite $(1 \%)$. The distinctive characteristic of quartz in this sample is occurrence as polycrystalline crystals. The microcline occurs as large subhedral crystals which are characterized by cross-hatched twinning. Plagioclase occurs as subhedral elongated crystals which are easily distinguished by their albite twinning (Figure 11: $\mathrm{H}$ and $\left.\mathrm{H}^{\prime}\right)$. 



Figure 10. (D) Muscovite Schist, $\left(12^{\circ} 40^{\prime} 03.5^{\prime \prime} \mathrm{N}, 08^{\circ} 24^{\prime} 09.2^{\prime \prime} \mathrm{E}\right)$ (E) Photomicrographs of Muscovite Schist XPL; (E') of Muscovite Schist PPL; NOTE: Pl = Plagioclase, Mv = Muscovite.

Granites are found rampant in almost everywhere in northern Nigeria. They were first named by Falconer (1911) as Older granites, to distinguish them from their newer an-orogenic or A-type granites that were emplaced during the Jurrasic period.

The rocks vary in dimensions from great elongate batholiths, tens of kilometers long and several kilometres across, aligned more or less parallel to the structural grain, to small sub circular stocks only a kilometer or two across (Rahaman, 1988). The larger bodies tend to be foliated and many of them are porphyritic, with feldspars reaching several centimeters in size, whereas the smaller intrusions are unfoliated and generally fine-grained.

Most of the inselbergs that characterize many of the landforms in the area are formed by erosion of these granitic masses, with their characteristic exfoliation weathering pat- 
terns. Where they are emplaced in the basement, the batholithic granites are commonly elongate and concordant and have gradational boundaries with surrounding gneisses and migmatites. The basement rocks become progressively more granitic in appearance as the intrusions are approached. For example, pegmatitic and aplitic veining becomes more common, there is metasomatic growth of feldspar crystals and banding becomes more diffuse. The smaller granite bodies generally have sharp boundaries that cut across the basement structures. Where they are emplaced into the supracrustal belts, however, even the larger granites generally have sharp cross-cutting boundaries. Intrusions of whatever size within the supracrustals may affect contact metamorphism of the schists and phyllites, leading to the development of 'spotted' rocks, due to the growth of minerals such as cordierite and andalusite.

\section{Chad Formation}

The far Chad basin in the northeast and the Sokoto basin in the north west are part of the Taodeni and Iulemeden Basins, which are found outside Nigeria with histories dating back to the Paleozoic (Whiteman, 1982; Kankara, 2014). Between the Chad and Keri-Keri Formations is a major break (Hiatus) which represented a period of non-deposition in the basin (Grant et al., 1972). Major rock types found within these basins are consolidated and unconsolidated sandstones, clays, siltstones, shale, ironstones, limestones, laterites, conglomerate, grits, mudstones, coal seams, etc. Some of the Formations are fossiliferous and some are oil-bearings (Cratchley et al., 1984)

Burke, (1976) described the Chad Basin as an active intra-continental Basin. The Chad Formation exists in the north-eastern part of the study area. It mostly occurs as sediments directly overlying the crystalline basement which frequently outcrops in this area. It appears as medium to coarse grained, yellowish white sand.

This is a geological basin, which is smaller than the drainage basin, is a Phanerozoic sedimentary basin formed during the plate divergence that opened the South Atlantic Ocean. The basin lies between the West African Craton and Congo Craton, and formed around the same time as the Benue Trough. It covers an area of about 2,335,000 square kilometres (902,000 sq mi) It merges into the Illo Basin to the west at the Damergou gap between the Aïr and Zinder massifs. The floor of the basin is made up of Precambrian bedrock covered by more than 3,600 metres (11,800 ft) of sedimentary deposits.

Here in the study area, the Chad formation is uncomformably overlying the basement, with sediments still accumulating in the lake which confirms it to be the youngest of the three (3) formations (Table 1) It has ultinate sand clay components. This unit only represents $2 \%$ of the total rock units in the Region. The sandstone unconformably overlies the basement, and two varieties of the sandstones were based on mineralogy, texture and general appearance.

They include ferruginous sandstone which is coarse grained and feldspathic sandstone which is fine to medium. The ferruginous variety is generally dark brown and rusty, consisting of poorly sorted quartz ( $40 \%$ of the rock), intensely weathered feldspars ( $30 \%$ of the rock), iron oxides ( $15 \%$ of the rock) and some rare mica flakes ( $2 \%$ of the rock). The fine to medium variety is a well sorted whitish grey rock, consisting of subangular to sub-rounded pebbles and boulders of quartz, feldspars, muscovite and iron 

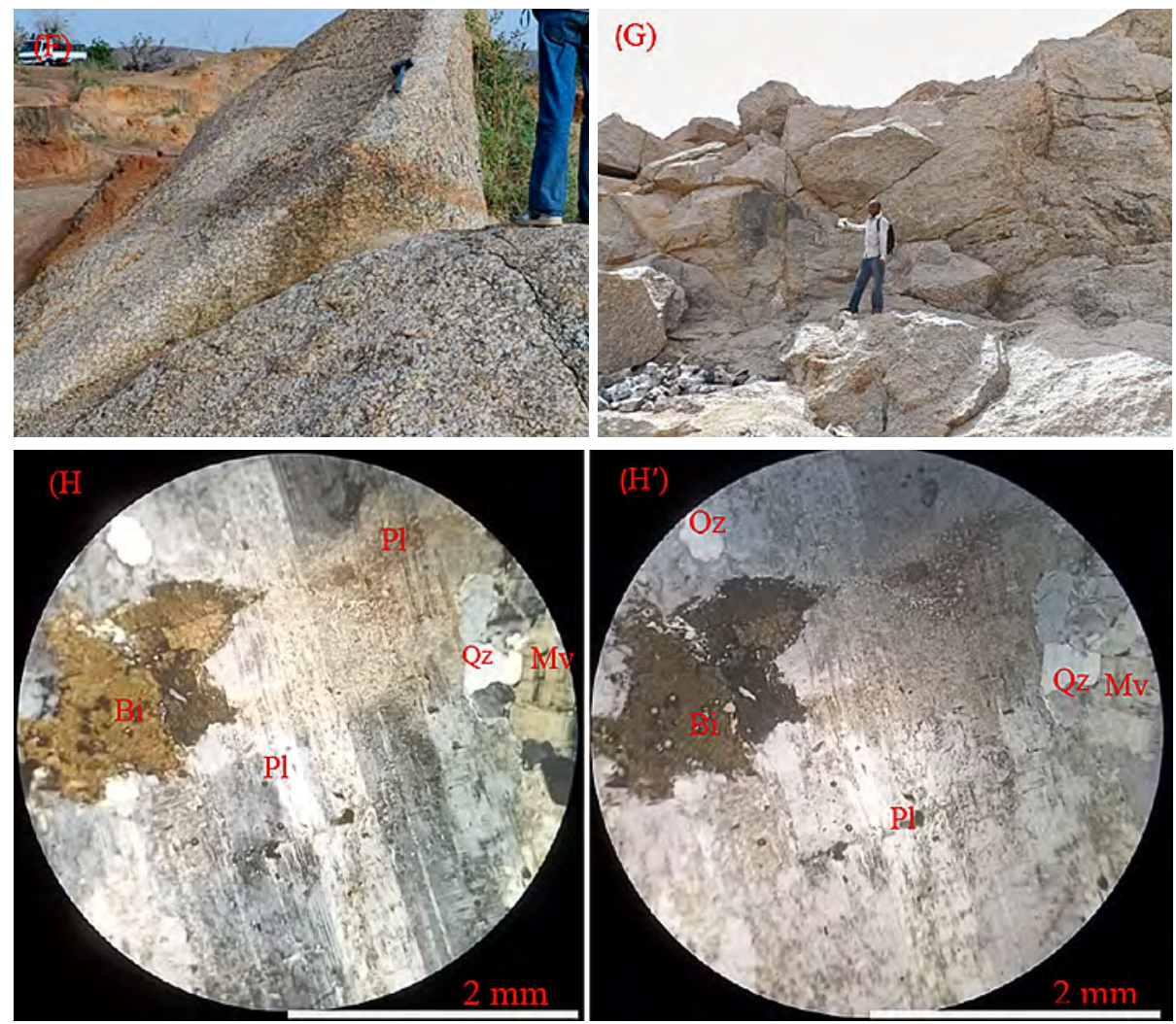

Figure 11: (G) Exposure of Porphyritic Granite, $\left(12^{\circ} 41^{\prime} 49.1^{\prime \prime} \mathrm{N}, 08^{\circ} 24^{\prime} 10.0^{\prime \prime} \mathrm{E}\right)(\mathrm{H})$ Joints in Porphyritic Granite, $\left(12^{\circ} 39^{\prime} 22.2^{\prime \prime} \mathrm{N}, 08^{\circ} 18^{\prime} 00.4^{\prime \prime} \mathrm{E}\right)(\mathrm{H})$ Photomicrographs of Porphyritic Granite XPL; (H') of Porphyritic Granite PPL; NOTE: Bi = BiotiteQz = Quartz, Mv = Muscovite, $\mathrm{Pl}=$ Plagioclase feldspar.

oxide. Cementing materials include fine-grained quartz, chlorite, green biotite, epidote and carbonates. The feldspatic sandstone is less ferruous and form the basal sandstone layer in. the state with the feldspars intensely altered into friable clays. Stratification in the sandstone is rarely observed.

In the study area, the Chad Formation exists in the south-eastern part. It mostly occurs as sediments directly overlying the crystalline basement which frequently outcrops in this area. It appear as medium to coarse grained, yellowish white sand.

\section{Justification for Groundwater Potential Development}

Geophysical Investigation: Vertical Electrical Sounding (VES) was carried out using an ABEM Terrameter SAS 300C. This survey was run by Global Earth Solve LTD Kano, within a period from 2008 up to 2014. A total of 30 VES stations across the study area were conducted. This data was obtained from this organization. It was interpreted and processed qualitatively and quantitatively using partial curve matching computer soft- 
ware techniques IPI2win to obtain the resistivity values of the total VES locations, their different subsurface layers and corresponding thickness. This permit drawing the geoelectric section profiles of some selected VES stations.

Physico-Chemical Analysis: Forty water samples from twenty different wells locations were collected. Plastic bottles were used for collection of the water sample, and at each sampling point the bottle was rinsed with the water to be sampled before the water was collected. Two water samples from each of these twenty wells, one acidified and the other non- acidified were carefully collected and packaged, labeled and transported to the laboratory.

In Chemical analysis, acidified water samples are used for the analysis of cations (Ogezi, 1977) as it was done for this research, whiles the other non-acidified water samples for the anions. Few drops of concentrated solution of nitric acid were added to the samples at the sampling points for the purpose of keeping the ions in solution and also to minimize reaction with the container wall. Coordinates of each of the wells were taken during the field work. During the collection of these samples, physical parameters such as temperature, conductivity, $\mathrm{pH}$ and total dissolved solids were obtained with the help of four-in-one meters (brand of the measuring meter was Mi 806 combined meter).

Part of the samples were analyzed at Multi-User Research Laboratory in Chemistry Department in ABU Zaria while, some at the Federal Ministry of Water Resources, Department of water quality control and sanitation, Zonal Office, Kano. The techniques for the analysis were Atomic Absorption Spectrophotometric (AAS), Flame photometer and Water Kit technology.

\section{DISCUSSION}

In this study, the geological mapping was done and the different lithologial units known, on a scale of 1: 50,000. Areas with groundwater prospects within the study area have been delineated and categorized as high, medium and low potential respectively. Groundwater configuration maps had been produced, which gave an insight of the direction of recharge and discharge of groundwater in the study area. Groundwater quality has been determined and documented, whereby areas with suitable water quality can be developed for use. The water type of (- ) has been established.

\section{Possible Model Establishment}

Model confirmation showed that areas of low groundwater potential and medium potential are characterized by thin overburden and weathered/fractured thickness of the basement aquifers while zones of high groundwater potential are characterized by thick overburden, low resistivity etc. Groundwater configuration maps of both dry and wet season indicated that groundwater in the area flows majorly toward southeast. The sources are from the high elevation of matasediment ridges of the area being the watershed and which dictated the direction of groundwater flow. 
The observed physical parameters of $\mathrm{pH}$, TDS, Temperature and Conductivity are within the WHO (2011) permissible limits for drinking water, except $\mathrm{pH}$ that falls below the standard level. High concentration of iron, cadmium and lead in groundwater of the area might be a result of acidic nature of the water analyzed. Lead ions also might have resulted from the application of pesticides chemicals, during wet season and irrigation farming. From the water quality analysis, it was observed the major cations are sodium and calcium while the anions are bicarbonate and chloride. The dominant water facie in the study is -. This might have been as a result of rock-water interaction of plagioclase feldspar of porphyritic granite. Result from salinity hazard of the water samples has indicated that, water of the area is good for irrigation. Generally, the result shows that the water of the Kazaure area is safe for drinking and domestic uses, based on the comparison with both NIS (2007) and WHO (2011).

\section{CONCLUSION}

This research work was set out to assess the geology, structural geology (condition) and groundwater potentials of part of Kazaure Area, sheet 35 Kazaure SE, Northwestern Nigeria. Six (6) thematic maps were digitized and prepared based on their influence on the occurrence of groundwater in the study area namely: elevation, slope, geology, lineament density, contact of water body proximity and drainage density. Groundwater potential modeling of the area revealed three zones of groundwater potential. These include zones of: low potential coinciding with rugged, high relief areas and low transmissivity $0.504625 \mathrm{~m}^{2} /$ day; medium potential zone coinciding with areas on crystalline basement, lower relief and transmissivity of about $1.401027 \mathrm{~m}^{2} /$ day; and high potential areas which occur in the sedimentary terrain, near the third order streams, water bodies and transmissivity of about $51.4 \mathrm{~m}^{2} /$ day.

The area is underlained by rock units, such as muscovite schist, porphyritic granite and Chad formation. Quartzite also occurs as minor rock in the area. The major structural features mapped in the area include joints, fractures and foliations with most trending in the NE-SW direction.

One major weakness of the Model is that, it operates with difficulty in the areas with rugged high relief. That is the reason why the areas have low yield.

\section{RECOMMENDATION}

Federal Government of Nigeria and other stake holders should establish a meteorological station in the area, to enable the rate of evapotranspiration and rate of recharge from precipitation to be established, for the appropriate management of the water resources. Care should be taken to make sure that the rate of groundwater exploitation does not exceed the recharge rate in order to avoid over abstraction, which could have environmental consequences. 


\section{REFERENCES}

Ajibade, A. C. Woakes and Rahaman, M. A. (1987). Proterozoic Crustal Development in the Pan - African Region of Nigeria, Copyright of the American geophysical Union, p. 259-271.

Anudu, G. K. Essien, B. I. Onuba, L. N. and Ikpokonte, A. E. (2011). Lineament analysis and interpretation for assessment of groundwater potential of Wamba and adjoining areas, Nasarawa State, Northcentral Nigeria. Journal of Applied Technology in Environmental Sanitation, 1 (2): 185-198.

Arthur, W. (1982). Nigeria: Its Petroleum Geology, Resources and Potential, Vol. 1 and 2. Sterling House 66, Wilton Road London SW IV IDE.

Black, R. Caby, R. Pouchcine, A. Bayer, B. Bertrand, J. M., Boullier, J. and Lesquer, A. (1979). Evidence for late Precambrian plate Tectonics in west Africa. Nature, 278, 223 $-337$.

Bowden, P. Van Breemen, O. Hutchison, J. and Turner, D. C. (1976). Palaeozoic and Mesozoic age trends for some ring complexes in Niger and Nigeria. Nature, 259, 297-299.

Burke, K. C., (1976). The Chad Basin: an active intra-continental Basin. Tectonophysics. 36, $19-206$.

Cratchley, G. R., Louis, P. and Ajakaiye, D. E. (1984). Geophysical and geological evidence for the Benue-Chad Basin Cretaceous Rift Valley system and its tectonic implications. Journal of African earth Sciences, 2, 140 - 50.

Danbatta, U. A. (1999). Geotectonic Evolution of the Kazaure Schist Belt in the Precambrian Basement of NW Nigeria. Published Ph. D. Dissertation. Ahmadu Bello University, Zaria, $289 \mathrm{p}$.

Danbatta, U. A. (2002). The structural Frame Work Underlying the Metamorphic Evolution of the Kazaure Schist Belt, NW Nigeria. Global Journal of Geological Sciences, 1(1), $73-83$.

Falconer, J.D. (1911). The geology and geography of Northern Nigeria. Macmillan, London, $135 \mathrm{pp}$.

Grant, N. K., Rex, D. C. and Freeth, S. J. (1972) Potassium-argon ages and strontium isotope ratio measurements from volcanic rocks in north eastern Nigeria. Contrib. Mineral. Petrol. 35, 277-92

Grant, N. K. (1978). Structural distinction between a metasedimentary cover and an underlying basement in the 600 my old Pan African domain of northwestern Nigeria. Geolsoc Am Bull 89, 50-58.

Gupta, R. P. (2003). Remote Sensing Geology. Springer Science and Business Media. ISBN 3540431853, 9783540431855. pp 532-533. Available from https://books.google.com. ng/.

Holt, R. W. (1982). The Geotectonic Evolution of the Anka Belt in the Precambrian Basement complex of NW Nigeria. Unpublished Ph.D. thesis, the Open University.

Ibrahim, A. A. (2003). Geological Setting and the Geochemistry of Iron Formations in the Kazaure Schist Belt, NW Nigeria. Unpublished M.Sc. Thesis. Ahmadu Bello University, Zaria, 89 p. 
Idris, M. A. (2012). Groundwater Potential Assessment of Part of Kazaure Area (Sheet 35 Kazaure SE), Northwestern Nigeria. An Unpublished MSc Thesis submitted to Dept. of Geology, Ahmadu Bello University Zaria.

Kankara, I. A. (2014). Geology and Geochemical Characterization of Rocks in Funtua Sheet 78, NE, Scale 1:30, 000, NW Nigeria. An unpublished PhD Thesis submitted to Dept. of Geology, Federal University of Technology, Minna, Nigeria.

Kankara, I. A. (2019). Mapping the Geology and Hydrogeochemical Character of DutsinMa Area., Katsina State, Nigeria.

Mc Curry, P. (1976). The Geology of the Precambrian to lower Paleozoic rocks of Northern Nigeria- A review In: Kogbe C.A (ed) Geology of Nigeria. Elizabethan Publishers, Lagos, pp 15-39.

McDonagh, M.S. Whiting, P.F., Wilson, P.M., Sutton, A.J., Chestnutt, I., Cooper, J., Misso, K., Bradley, M., Treasure, E. and Kleihnen, J., (2000). Systematic review of water fluoridation. Brit. Med. J., 321, 855-859.

Mostafa, M.E. Bishta, A.Z. (2005). Significant of lineament pattern in rock unit classification an designation: A pilot study on the Gharib-Dara area. Northeastern Desert, Egypt. International Journal Remote Sensing, 26(7). 1463 - 1475.

Ogezi, A. E. O. (1977). Geochemistry and Geochronology of Basement Rocks from NW Nigeria. Unpublished Ph.D. Thesis. University of Leeds, England.

Raeburn, C. and Jones, B. (1934). The Chad basin: Geology and water supply: Bull. Geology. Survey, 15, 20 - 23.

Rahaman, M. A. (1988). Recent advances in the study of the basement complex of Nigeria (ed) Precambrian Geol survey of Nigeria, pp 11-43.

Turner, D. C. (1983). Upper Proterozoic schist belts in the Nigerian sector of the Pan-African province of West Africa, Precambrian Research, 21, 55-79.

Umaru, A. O., Danbatta, U. A., Kankara, I. A., Muhyideen, H., Kamale, H. I., Kitha, M., Abdulmalik, N. F. and Adamu, L. M. (2019). Mapping Tectonic Lineamnets in The Pre-Cambrian Terrain of Zuru Schist Belt, Northwestern Nigeria. Minna Journal of Geosciences (MJG), 4, 1.

Whiteman, A. (1982): Nigeria: Its Petroleum Geology, Resources and Potential. Graham and Trotman Ltd. London, pp 82-86.

\section{CONFLICTS OF INTEREST}

The author(s) declared no potential conflicts of interest with respect to the research, authorship, and/or publication of this article.

(C) 2020 by the authors. This article is an open access article distributed under the terms and conditions of the Creative Commons Attribution (CC BY) license (http://creativecommons.org/licenses/by/4.0/). 